\title{
Reply to "Comment on "Stratigraphy of the Northern Pulo do Lobo Domain, SW Iberia Variscides: A palynological contribution» by Zélia Pereira et al. (2018) - Geobios 51, 491-506" 话
}

\author{
Zélia Pereira $^{\mathrm{a}, *}$, Paulo Fernandes ${ }^{\mathrm{b}}$, João X. Matos $^{\mathrm{c}}$, Raul C.G.S. Jorge ${ }^{\mathrm{d}}$, José T. Oliveira ${ }^{\mathrm{e}}$ \\ a LNEG, Rua da Amieira, Ap. 1089, 4466-901 S. Mamede Infesta, Portugal \\ ${ }^{\mathrm{b}}$ Centro de Investigação Marinha e Ambiental (CIMA), Campus de Gambelas, Universidade do Algarve, 8005-139 Faro, Portugal \\ ${ }^{\mathrm{c}}$ LNEG, Centro de Estudos Geológicos e Mineiros do Alentejo, Bairro da Vale d'Oca, Ap. 14, 7600-020 Aljustrel, Portugal \\ ${ }^{\mathrm{d}}$ Faculdade de Ciências, Universidade de Lisboa, Campo Grande, Edifício C6, Instituto Dom Luiz (IDL), Piso 4, 1749-016 Lisboa, Portugal \\ e LNEG, Ap. 7586, 2611-901 Amadora, Portugal
}

A R T I C L E I N F O

Historique de l'article

Received 26 March 2019

Accepted 21 June 2019

\section{Keywords:}

Palynomorphs

$\mathrm{U}-\mathrm{Pb}$ Zircon ages

Northern Pulo do Lobo Domain

SW Iberia

We acknowledge M. Francisco Pereira, D. Martínez Poyatos, I. Pérez-Cáceres, Cristina Gama and António Azor for the interest shown in our work, and appreciate the chance to clarify a few questions raised by Pereira et al.'s (2018) research. The main aim of Pereira et al. (2018) study was to better constrain the ages of the lithostratigraphic units that make the Northern Pulo do Lobo Domain, SW Iberia Variscides. For the first time, all units were dated based on palynostratigraphy, i.e., the study of palynomorphs content, miospores and acritarchs. A total of 139 shale samples, of which 56 are positive for palynology, were studied, being representative of the Pulo do Lobo Fm. and the overlying Ribeira de Limas, Santa Iria and Horta da Torre formations in Portugal and Spain (Pereira et al., 2006, 2018). Our study also included for the first time, samples from the imbricated phyllites of the Peramora and Alájar Mélanges, which were tested with positive results for palynology (Fig. 1). Sampling was controlled by detailed geological mapping and rigorous interpretation of the sedimentary facies and geometric relations. Our response will focus on the most controversial geological units, which raised the main comments to our study, the Peramora Mélange and the Santa Iria Fm. It is worth noting that in our study, the only positive sample from the

DOI of original article: https://doi.org/10.1016/j.geobios.2019.06.003

Corresponding editor: Gilles Escarguel.

* Corresponding author.

E-mail address: zelia.pereira@lneg.pt (Z. Pereira).
Peramora Mélange (Fig. 1(A)) corresponds to the Imbricated Schist sensu Dahn et al. (2014), and the samples from the Santa Iria Fm. are from several areas located in Portugal (Serpa south) and Spain (Peramora and Almonaster) (Fig. 1).

The main comments made by M.F. Pereira et al. to Pereira et al. (2018) relate to the discussion of the palynological age $v s$. $\mathrm{U} / \mathrm{Pb}$ geochronological age based on detrital zircons, stating that "this discussion is inconsistent due to: (i) the impossibility that primary igneous ages in zircon grains would have been rejuvenated during Early Carboniferous low-grade regional metamorphism, and (ii) a wrong interpretation of the meaning and implications of maximal depositional ages derived from the youngest detrital zircon population".

Regarding the first point, M.F. Pereira et al. state that "Pereira et al. (2018) notice the conflict between some of the youngest detrital zircon population ages and the attributed palynological ages (for instance, in the Santa Iria Formation), i.e. detrital zircon ages cannot be younger than biostratigraphic ages. They solve the problem by simply arguing a disturbance ("temporary leakage" in their own words) in the U-Th isotopic system of zircon caused by metamorphism and deformation, but this is untenable in the case of the Pulo do Lobo Unit". In our work we focused our discussion solely on the Peramora Mélange based on the data and interpretations of Dahn et al.'s (2014) and Pérez-Cáceres et al.'s (2015) works. The sample we dated by palynomorphs from the "imbricated" shales of the Peramora Mélange (Fig. 1), yielded a mid Frasnian age similar to the Pulo do Lobo age dated from palynomorphs in other locations. This sample was collected from highly deformed shales intercalated with both mafic blocks and matrix sensu Dahn et al. (2014). For us it is not clear from field evidences that the contact between the shales and the Peramora mafics corresponds to tectonic imbrications, suggesting that the Peramora mafic rocks are intrusive in the Pulo do Lobo Fm. If the interpretation favoured by Eden (1991), Dahn et al. (2014), and Pérez-Cáceres et al. (2015) of the Peramora Mélange being initially an olistostrome, later tectonically imbricated with the Pulo do Lobo Fm. lithologies is accepted, then the sedimentary matrix floor where the olistostrome was emplaced must by younger or with the 


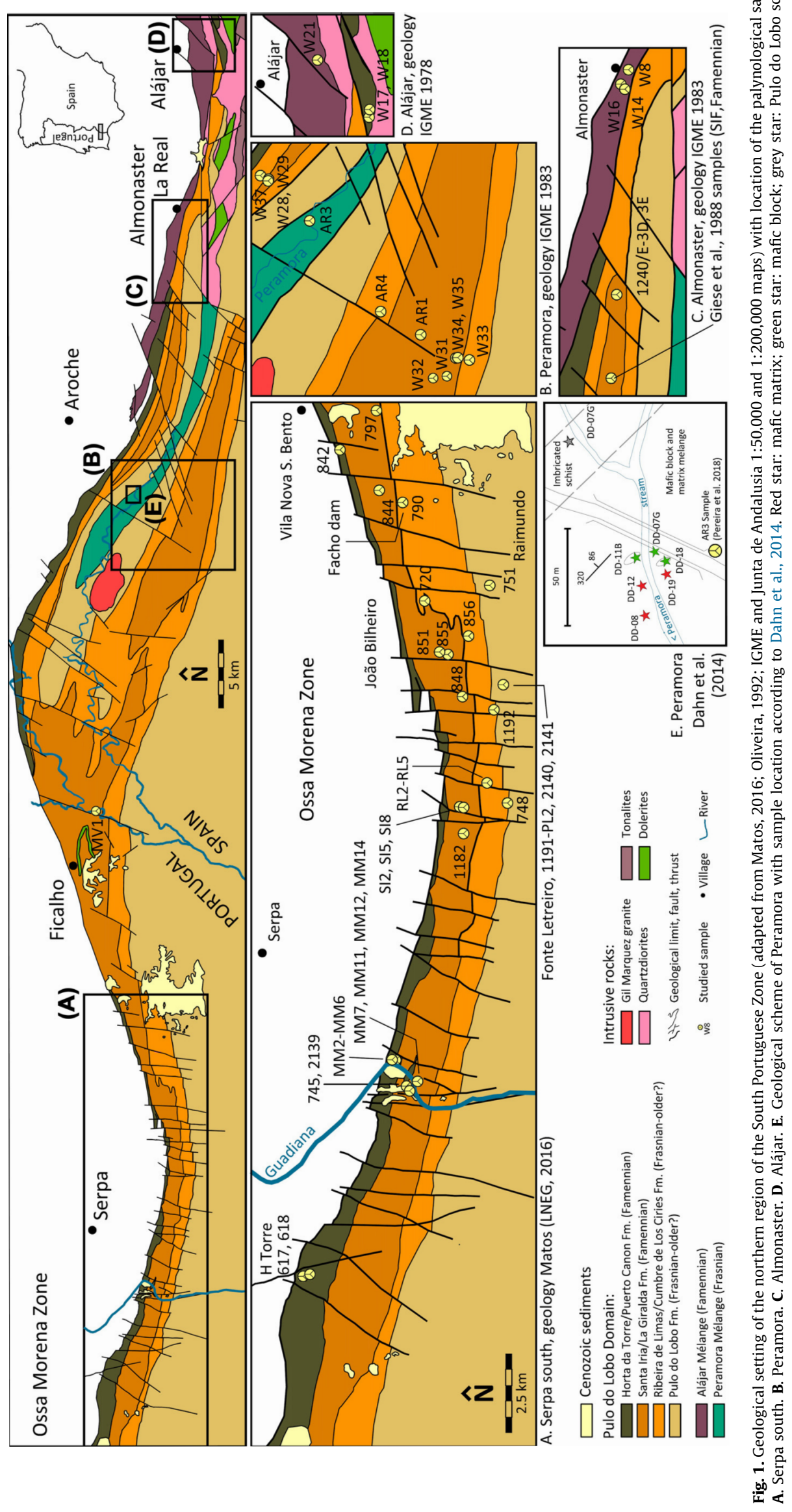


same age of the Peramora mafics, i.e., Tournaisian to Visean. According to Pérez-Cáceres et al. (2015) these rock units should be time equivalent to the Santa Iria Fm., and also to the Horta da Torre Fm. The similarity of ages of both the Peramora mafic blocks and matrix (337 Ma and $342 \mathrm{Ma}$, respectively), suggested to Dahn et al. (2014) that the mafic matrix of the Peramora Mélange could have been the volcano-sedimentary floor where the mafic blocks (olistostromes) were emplaced and mixed with sediments. The comparison of the U-Pb age spectra of the zircons of the Peramora mafic matrix with the U-Pb age spectra of the likely sediments that were mixed during the olistostrome emplacement was never tested. Dahn et al. (2014) states that the age spectra of zircons from the Peramora mafic matrix is similar to that of the Pulo do Lobo schists. As mentioned above the only comparison established is based on the maximum deposition age of the Santa Iria detrital zircons (ca. 344 Ma, early Visean; Pérez-Cáceres et al., 2017) with the youngest age of the igneous zircon from the Peramora mafics (ca. 342-337 Ma, early to mid Visean). However, this range of ages was, up to now, not recognized in neither of the lithostratigraphic units of the Pulo do Lobo Domain (Pulo do Lobo, Ribeira de Limas, Santa Iria, and Horta da Torre study areas in Portugal and Spain) by means of palynology. The authors solve this problem favouring $\mathrm{U}-\mathrm{Pb}$ zircon ages over palynomorphs ages claiming that the late Famennian age given by palynomorphs to the Santa Iria Fm. and by inference to the Horta da Torre Fm., corresponds entirely to reworked assemblages. The question related to the U-Pb loss was not raised by us but by Dahn (2014: p. 1243): “All rock types in the $\mathrm{PM}$ contain some zircon grains that have ${ }^{206} \mathrm{~Pb} /{ }^{238} \mathrm{U}$ ages younger than ca. 339 Ma. We interpret these zircon grains to have experienced $\mathrm{Pb}$-loss, possibly due to protracted magmatism associated with the emplacement of the Gil Marquez composite pluton (Gladney et al., 2014)".

Concerning the second point, M.F. Pereira et al. state that Pereira et al. (2018) made "a wrong interpretation of the meaning and implications of maximal depositional ages derived from the youngest detrital zircon population." We refute this allegation. Our discussion was based on a correct interpretation of maximum depositional ages found in detrital sedimentary rocks. The maximum depositional ages of detrital zircons quoted in our discussion were all from previous geochronological studies (Braid et al., 2011; Dahn et al., 2014; Pérez-Cáceres et al., 2015, 2017; Pereira et al., 2017). In our discussion we wanted to drawn attention to the conflict that exists in the age of the Santa Iria Fm. given by the youngest age of detrital zircons (ca. $344 \mathrm{Ma}$, early Visean; Pérez-Cáceres et al., 2017) and the age given by palynomorphs (ca. 372-359 Ma, late Famennian; Cohen et al., 2013, updated). We further developed this discussion assuming that the maximum depositional age given by the detrital zircons is correct for this stratigraphic unit, and its implication for the local stratigraphic column and tectonic history. M.F. Pereira et al. defends the idea that "the slight inconsistency between detrital zircon age content in the Santa Iria Fm. (Early Carboniferous) and its palynomorph age (Late Devonian) can only be due to either an undetected palynomorph redeposition or to an overlap in the age confidence intervals that both methodologies entail." The "slight inconsistency" (their own words) concerning the age of the Santa Iria Fm. (the most studied unit of the Pulo do Lobo Domain concerning detrital zircon geochronology) shows the widest age spectra recorded from outcrops in Portugal and in Spain: Early Carboniferous age of about ca. 347 Ma (late Tournaisian; Braid et al., 2011), $344 \pm 4$ Ma, (Visean; Pérez-Cáceres et al., 2017), and $376 \pm 4$ Ma (Frasnian; Pereira et al., 2017) vs. a late Famennian age provided by the miospores assigned to the $\mathrm{VH}$ (Apiculiretusispora verrucosa-Vallatisporites hystricosus) Miospore Biozone.

The authors elucidate that the palynomorph assemblages studied in Pereira et al. (2018) were statistically robust, with each sample yielding hundreds of palynomorphs specimens (>300). Moreover, palynological studies of rocks of Late Devonian to Mississippian age involve a high-resolution correlation between Miospore Biozones and Global Standard Conodont Zones. Using this approach enables to pinpoint the Devonian-Carboniferous Boundary ( $c$. $359 \mathrm{Ma}$ ), and biozones within the Famennian (Higgs et al., 2013; Streel et al., 2000; Kalvoda, 2002). During the late Famennian, the transition between the Lower and Middle Palmatolepis expansa Conodont Zone can be correlated with the base of the VH Miospore Biozone. The top of the Middle Palmatolepis expansa zone is correlated with the middle part of the LL Miospore Biozone, providing a numerical age for the Middle Palmatolepis expansa Conodont zone between $\mathrm{ca}$. 362.8 and $\mathrm{ca}$. 363.5 Ma, therefore constraining the time interval of the $\mathrm{VH}$ Miospore Biozone between $\mathrm{ca}$. 363 and $363.5 \mathrm{Ma}$.

The well-constrained late Famennian age of the Santa Iria Fm. provided by palynomorphs is ca. 19 myr older than the youngest maximum depositional age obtained for this formation (ca. 344 Ma; Pérez-Cáceres et al., 2017). In our opinion this not a "slight inconstancy" and this is above the error intervals of the detrital zircons geochronology presented by M.F. Pereira et al. Another aspect that our palynological data does not support, due to the constancy of late Famennian age regardless the geographic position, is the sedimentation time range of the Santa Iria Fm. during the Late Devonian to latest Tournaisian time interval (Pereira et al., 2017). Lastly, considering a Late Devonian to latest Tournaisian age for the Santa Iria Fm. implies that the Horta da Torre Fm. should be of a younger age, or at least of the same age. In fact, the black shales interbedded with $\mathrm{cm}$-thick quartz-sandstones of the Horta da Torre Fm. both in outcrops located in Portugal and Spain, provided several productive samples with wellpreserved miospores assemblages assigned to the basal, late Famennian VH Miospore Biozone. Not a single miospore of Tournaisian/Visean age was found in the palynological content of this unit.

Concerning the "undetected palynomorph redeposition" statement, it has been systematically used to justify the age discrepancies between palynomorphs and U-Pb detrital zircons geochronology (Pérez-Cáceres et al., 2015, 2017). In our point of view this is not a valid argument. As was emphasized by Pereira et al. (2018), the miospore assemblages identified in the Pulo do Lobo Domain correspond to in situ assemblages. Early Devonian reworked palynomorphs were also found (Pereira et al., 2018), which are clearly distinct from the in situ palynomorphs based in their morphologic features. It seems most unlikely that during a period of time when land plants had a fast evolution and diversification (Late Devonian to Mississippian), the continental source regions of the Pulo do Lobo Domain were barren of vegetation and the marine basins where sediments were being deposited had a phytoplankton shutdown. Noteworthy, not a single typical palynomorph (spores, algae and acritarchs) of Tournaisian/Visean age was found in the studied samples (Pereira et al., 2006; 2018). Moreover, reworked palynomorphs tend to be broken or damaged due to the effects of weathering and erosion during transport, but this was not observed in the studied assemblages (see microfossil plates in Pereira et al., 2018), where even delicate spore tetrads are common, suggesting the presence of in situ palynomorphs.

Finally, the assertion that "an overlap in the age confidence intervals that both methodologies entail" seams more plausible to justify the age discrepancies. Both methodologies are valid; however, for stratigraphic successions that are dated by fossils (micro- or macrofossils) and lack clear tephra layers or clear evidences of synsedimentary volcanic activity, fossils are probably more useful to date sedimentary basins. 


\section{References}

Braid, J.A., Murphy, J.B., Quesada, C., Mortensen, J., 2011. Tectonic escape of a crustal fragment during the closure of the Rheic Ocean: U-Pb detrital zircon data from the Late Palaeozoic Pulo de Lobo and South Portuguese Zones, Southern Iberia. Journal of the Geological Society of London 168, 383-392.

Cohen, K.M., Finney, S.C., Gibbard, P.L., Fan, J.X., 2013. The ICS International Chronostratigraphic Chart. Episodes 36, 199-204.

Dahn, D.R.L., Braid, J.A., Murphy, J.B., Quesada, C., Dupuis, N., McFarlane, C.R.M., 2014. Geochemistry of the Peramora Melange and Pulo do Lobo schist: geochemical affinity of the South Portuguese Zone and the Neoproterozoic evolution of SW Iberia through detrital zircon populations. Gondwana Research 42, 177-192.

Eden, C.P., 1991. Tectonostratigraphic analysis of the Northern Extent of the Oceanic Exotic Terrane, Northwestern Huelva Province, Spain. The University of Southampton, 281 (Ph.D. Thesis, unpubl.).

Higgs, K.H., Prestianni, C., Streel, M., Thorez, J., 2013. High-resolution miospore stratigraphy of the Upper Famennian of eastern Belgium and correlation with the conodont zonation. Geologica Belgica 16, 84-94.
Kalvoda, J., 2002. Late Devonian-Early Carboniferous foraminiferal fauna: Zonations, Evolutionary Events, paleobiogeography and tectonic implications. Folia: Geologia 39, 1-213.

Lithos 278-281, 383-399.

Pereira, Z., Fernandes, P., Oliveira, J.T., 2006. The Upper Devonian Palynostratigraphy and Organic Matter Maturation of the Pulo do Lobo Domain, South Portuguese Zone, Portugal. Comunicações Geológicas 93, 23-38.

Pereira, Z., Fernandes, P., Matos, J.X., Jorge, R.C.G.S., Oliveira, J.T., 2018. Stratigraphy of the Northern Pulo do Lobo Domain, SW Iberia: a palynological contribution. Geobios 51, 491-506.

Pérez-Cáceres, I., Martínez Poyatos, D., Simancas, J.F., Azor, A., 2015. The elusive nature of the Rheic Ocean suture in SW Iberia. Tectonics 34, 2429-2450.

Pérez-Cáceres, I., Poyatos, D.M., Simancas, J.F., Azor, A., 2017. Testing the Avalonian affinity of the South Portuguese Zone and the Neoproterozoic evolution of SW Iberia through detrital zircon populations. Gondwana Research 42, 177-192.

Streel, M., Caputo, M.V., Loboziak, S., Melo, J.H., 2000. Late Frasnian-Famennian climates based on palynomorph analyses and the question of the Late Devonian glaciations. Earth-Science Reviews 52, 121-173. 